\title{
ØKONOMI OG DEMOKRATI
}

En historisk analyse av de arabiske landene, Iran og Tyrkia, med vekt på hvilken innvirkning den økonomiske utviklingen har hatt på demokratiseringen. 
TEKST: Kjetil Selvik

KAN MANGELEN PÅ demokrati i Midtøsten og Nord-Afrika ha økonomiske årsaker? Denne artikkelen retter søkelyset mot sammenhenger mellom politisk og økonomisk organisering i den arabiske verdenen, Tyrkia og Iran. Målet er å peke på fellestrekk i landenes historiske utvikling som kan forklare den muslimske verdens autoritære politiske systemer uten å bruke argumenter som at "islam bare er sånn". Et av de største problemene for området i dag, er for eksempel at de som styrer politikken som regel også dominerer det økonomiske livet, enten det nå gjelder kongefamilien i Saudi-Arabia, militæret i Algerie eller presteskapet i Iran. De herskende har dermed tungtveiende økonomiske insentiver til å nekte befolkningen adgang til politiske beslutninger. Samtidig eksisterer fellestrekk i landenes produksjonsstruk- tur som gjør det vanskelig for samfunnet å presse eliten til en deling av makt. For å vekke oppmerksomhet om denne typen mekanismer vil det være nødvendig å generalisere, og hensynet til knapphet hindrer dessuten detaljbeskriver av variasjonene innen hvert enkelt land. Likevel skal vi være på vakt mot perspektiver som blir så store at de gir grobunn for stereotypier. Marx har i sin tid syndet mot dette gjennom sin teori om at klassedelte jordbrukssamfunn utenfor Europa utgjorde en egen "asiatisk produksjonsmåte”. Villedet av fellesskapets betydning i "de asiatiske samfunn" analyserte Marx seg frem til en produksjonsmåte han mente var blottet for privat eiendom, for borgerskap og for urbanisering. Den asiatiske produksjonsmåten var grunnet $\sin$ kollektive organisering nærmest immun mot indre utvikling, og ville kun gi etter for endring når det ytre presset ble for sterkt fra den kapitalistiske verdensøkonomien. Økonomiske strukturer i Midtøsten og Nord-Afrika har imidlertid aldri vært ensartede eller uforanderlige. La oss ikke gå i orientalismens felle der den muslimske verden fremstilles som en unntaksmessig dimensjon, "styrt av sine egne lover og regler”. Det er ikke ved å lete etter en "annen økonomisk rasjonalitet", men ved å studere forskjeller i historisk kontekst at vi kan skjønne hvorfor overgangen til kapitalisme ikke har hatt den samme demokratiserende effekt i Midtøsten og Nord-Afrika som i Vesten.

Hvilke problemer er det imidlertid legitimt å bruke økonomi til å forklare? Helt siden S. M. Lipsets klassiske artikkel fra I959 har moderne demokratiteori pekt på sammenhenger mellom fattigdom og fravær av representativt styre ${ }^{2}$. Jo høyere et lands velstandsnivå, argumenterte Lipset, 
dess større er sjansen for å finne et levende politisk system: økonomisk vekst gir nemlig bedre utdanning og styrker den urbane middelklassen (en gruppe amerikanske akademikere betraktet som en buffer mot kommunismens tyranni under den kalde krigen). Utviklingen i Midtøsten og NordAfrika siden I960-tallet har imidlertid ikke gått slik Lipset og andre hadde håpet. Brutto nasjonalprodukt per innbygger har steget betraktelig i en rekke land, sælig i begynnelsen av perioden. Velstandsøkningen har imidlertid ikke forvandlet områdets autoritære politiske system til levende folkestyrer. I Sørøst-Asia har utviklingen i "tigerstater" som Singapore og Taiwan kastet enda mer tvil over Lipsets

\section{man \\ Velstanden har ikke forvandlet områdets autoritoere politisk system til levende folkestyrer.}

hypotese om velstand og vekst. Så hvilken sammenheng kan egentlig eksistere mellom økonomi og demokrati? Det vi trenger er en analyse som ikke bare forholder seg til tall fra makronivået, men også gir bedre innsikt i hvordan den økonomiske utviklingen påvirker maktforholdene i samfunnet. For tilgang til politiske beslutninger er til syvende og sist et spørsmål om deling av goder og makt. Kan man fremme en økonomisk utvikling som forhindrer staten, overklassen eller én enkelt sosial gruppe i å monopolisere all rikdom, har man gått et viktig steg i retning av pluralisme. Marx var kanskje ingen stor orientalist, men den historiske materialismen er fortsatt interessant som metode, så la oss bruke den til å avlede følgende problemstilling: hvilke endringer i produksjonsstrukturen kan vi peke på i Midtøsten og Nord-Afrika, og hva har vært deres følger på det politiske plan?

Det klassiske svaret "orientalsk despoti”, formulert av Karl Wittfogel i I957, er nå mest å regne for en kuriositet? ${ }^{3}$. Den tyskamerikanske historikeren videreførte sentrale aspekter fra teorien om den asiatiske produksjonsmåten, og grep sælig fatt i forklaringen på hvorfor statsapparatet hadde vokst seg så stort over store deler av Asia mens det forble svakt i det føydale Europa. De tørre landområdene i øst krevde nemlig avanserte systemer for vanntilførsel, og dermed også mektige byråkratier for å administrere dem. Wittfogels hypotese var at elver som Nilen, Eufrat og Tigris hadde gitt grobunn for "hydrauliske sivilisasjoner", hvor utbyggingen av sinnrike vanningsanlegg førte store arbeidsstyrker inn under statshierarkiets nådeløse kontroll. Slik ble grunnlaget lagt for det "orientalske despoti”. Ifølge Wittfogel skulle denne styreformen, som blant annet støttet seg på autoritære statsreligioner, komme til å prege store deler av Midtøstens historie. Arkeologer og antropologer har imidlertid stilt spørsmålstegn ved flere av premissene for Wittfogels konklusjoner, som for eksempel at vanningssystemene virkelig skulle være så avgiørende for samfunnsstrukturen som den dogmatisk marxistiske modellen hevder. I forlengelsen av kritikken av "den asiatiske produksjonsmåte" har konseptet dessuten blitt anklaget for å underkjenne kompleksiteten og dynamikken i Midtøstens historie: teorien om "orientalsk despotisme” er rett og slett for statisk til å fange opp eventuelle endringer i produk- 
sjonsstrukturen, og tilskrives ikke stor forklaringsverdi i dag.

\section{Max Weber}

En klassiker som har holdt seg litt bedre (til tross for sin eurosentrisme) er Max Weber, og hans betraktninger rundt ulikheter mellom føydalisme i Vesten og den ubegrensede livegenskap han kaller "patrimonialisme” i Orienten. En grunnleggende forløper for utviklingen av demokrati i Europa, hevder Weber, var nemlig rettighetstenkningen som gjennomsyret middelalderens sosiale organisering: vasall og føydalherre hadde begge visse lovfestede rettigheter og plikter, som på et idéhistorisk nivå kan sies å ha lagt grunnlaget for den moderne rettsstat. I Midtøsten derimot, hvor statsbyråkratiet tradisjonelt var mektigere, fortsatte styreren å betrakte samfunnet som sin personlige besittelse: innbyggerne nøt kun privilegier distribuert av sultanen. Lojale tjenere kunne innvilges disposisjonsrett over produksjonsmidlene, men et slikt privilegium skulle ikke gå $i$ arv og kunne alltid inndras dersom forholdet til sultanen ikke ble pleiet. Virkelig privat eiendomsrett eksisterte med andre ord ikke ifølge Webers modell: det var forholdet til velgjøreren, og ikke til produksjonsmidlene, som bestemte innbyggernes plass på den sosiale rangstigen. Følgelig fikk heller ikke sosiale klasser den samme betydningen som i Europa, for avhengigheten av støtten ovenfra, de vertikale bånd, la en demper på klassefølelsen og utviklingen av de horisontale bånd. To sentrale elementer fra Europas demokratiseringshistorie har med andre ord vært svake i Midtøstens og Nord-Afrika ifølge Weber, nemlig rettslig legitimering og klassekamp. Overgangen til demokratiet ville vært utenkelig uten skrevne lover og regler, men også uten sosiale grupper som satte makt bak kravene om representativt styre. Borgerskapet ble kjent som den "liberale klasse" etter å ha utfordret adelens privilegier gjennom den franske revolusjonen, men det man heller ikke skal glemme er arbeiderklassens lange kamp for å bli hørt: de førstnevntes press for demokratisering stoppet ofte opp når "ansvarlige menn med eiendom" hadde fått sin stemmerett.

\section{Kapitalisme og demokrati}

Hva så med den konkrete økonomiske utviklingen i Midtøsten og Nord-Afrika på I8- og I9०o-tallet? Det viktigste som bør understrekes er utvilsomt hvordan området har blitt integrert i den kapitalistiske verdensøkonomien og som en konsekvens av dette langsomt har tilpasset sin egen produksjonsmåte. I kjølvannet av den industrielle revolusjonen opplevde Europa sterk vekst, mens Det osmanske riket slet med å holde følge økonomisk og militært. Der industrinasjonene utnyttet fordelene ved kapitalbasert produksjon, stammet overskuddet $\mathrm{i}$ imperiet fortsatt hovedsakelig fra handel og jordbruk. Nesten all dyrkbar jord var i prinsippet statseid hvor bøndene betalte skatt av det de høstet. Helt siden slutten av I500-tallet hadde imidlertid sultanen begynt å auksjonere ut rettigheter til skatteinnkreving i provinsene på forhånd for å dekke utgiftene til sin stadig mer kostbare stående hær. Delegeringssystemet genererte uregjerlige småkonger i provinsene, som ofte presset bøndene langt utover det som var hensiktsmessig for produksjonen og unndro store ressurser for Istanbul for å styrke sin egen maktbasis. Etter hvert ble skatteinnkrevingen så lite effektiv og sultanens militære 
overlegenhet så lite merkbar, at provinser i utkanten av riket begynte å løsrive seg, for ikke å si, som under Muhammed Ali i Egypt, å gå til storangrep på osmanske tropper. Trusselen fra Muhammed Ali var en av de viktigste årsakene til at sultanen gav etter for press fra europeiske stater som ønsket fri tilgang til området for sine industrivarer, og signerte Balta-Liman-avtalen (I838) for nedbygging av osmanske tollbarrierer som umiddelbart undergravde I830tallets egyptiske forsøk på industrialisering. Midtøsten og Nord-Afrika måtte pent legge om til salgsjordbruk for i finne sin plass i den nye verdensøkonomien ${ }^{4}$.

Omstillingen til en kapitalistisk produksjonsmåte startet gjerne i eksportområdene langs kysten og spredte seg gradvis til innlandsområdene gjennom bedringer i transportstrukturen og økende investeringer. Den europeiske innflytelsen på utviklingen ble etter hvert større, ettersom sultanen fra I850-tallet måtte giøre seg til lånekunde for å finansiere sine kriger og reformer. Spørsmålet i denne sammenheng er hvilke følger den økonomiske endringsprosessen har hatt for det politiske liv, og om den kan ha lagt hindringer i veien for senere forsøk på demokratisering. Det som vanligvis forventes av kapitalismen er at den skal bidra til å sprenge gamle maktstrukturer nedenfra. I land som Frankrike og Storbritannia gjorde nemlig "den nye økonomien" borgerskapet i stand til å utfordre føydaleliten. Det faktum at demokratiet aldri noensinne har eksistert uten at man samtidig har anerkjent retten til privat eiendom, har dessuten blitt tatt til inntekt for kapitalismens demokratiserende effekt. I den fremragende boken «Capitalist Development and Democracy» avviser imidlertid forfatterne at det finnes en iboende strukturell sammenheng mellom kapitalisme og demokrati: det som giør at den kapitalistiske utvikling i mange land har utløst demokratiseringsprosesser er at den forandrer klassestrukturen ved å styrke arbeiderog middelklassen og svekke den autoritære jordeieradelen'. I Midtøsten og Nord-Afrika hadde imidlertid den økende innflytelsen fra kapitalismen på mange måter motsatt effekt, fordi overgangen til eksportrettet salgsjordbruk i realiteten styrket provinsherrenes posisjon. Staten ble gradvis mer avhengig av ensrettet jordbruksproduksjon for å dekke de økende utgiftene: Libanon spesialiserte seg på silke, Egypt ble "bomullsplantasje" for tekstilprodusentene i Lancashire, Tyrkia eksporterte frukt og ull, mens Iran tilpasset seg verdensmarkedets økende behov for tobakk og opium. Samtidig ble sentralmakten svekket under vekten av den økende gjeldsbyrden: $\mathrm{i}$ I875 var Det osmanske riket i realiteten konkurs og måtte godta direkte internasjonal finanskontroll. I fraværet av en sterk sentralmakt vokste betydningen av autoriteter i provinsene, de såkalte notables, som mellommenn mellom Istanbul og befolkningen.

Møtet med kapitalismen styrket dermed i grove trekk den jordbundne overklassen, en gruppe faglitteraturen siden Barrington Moores klassiske komparative studie har betraktet som hovedmotstandere av demokratisering 6 . Selv om privat eiendomsrett over jordbruksområdene formelt ikke ble innvilget i Det osmanske riket før etter Den første verdenskrig, understreket landlovene av I 858 og I 867 at disposisjonsretten måtte styrkes for å fremme investering og skatteinntekter. I de tyrkiske kjerneområdene av riket forble det patrimonialis- 
tiske systemet fra Webers beskrivelse sterkt og hindret fremveksten av en selvstendig landeierklasse. I provinsene, derimot, førte utviklingen paradoksalt nok til en økende "føydaliseringsprosess". Landreformloven av I858 førte for eksempel til at stammeledereliten i de irakiske områdene tok farvel med nomadetilværelsen og slo seg ned som mektige jordeiere. I Egypt hadde Muhammed Ali allerede distribuert store statlige områder til landeiere som snart la om til bomullsproduksjon for verdensmarkedet. Samtidig uteble den store styrkingen av arbeider- og middelklassen, fordi Midtøsten og Nord-Afrika ikke ble skikkelig industrialisert før godt ut på I9oo-tallet. I Europa hadde fabrikkene absorbert det voksende overskuddet av bønder fra tradisjonelt jordbruk og skapt en pressgruppe av industriarbeidere $i$ byene. I Det osmanske riket fjernet imidlertid frihandelsavtaler som Balta Liman muligheten til å beskytte lokal industri i en etableringsfase. Roger Owens statistikk fra I90 I forteller om sørgelige 23 moderne industribedrifter i foregangslandet Egypt, som riktignok hadde øket til 37 i I 9 II, mens ingen motordrevne fabrikker eksisterte i Irak før I9I4ㄱ. Situasjonen var ikke bedre i Iran, hvor I700 personer var ansatt i moderne industriproduksjon ved inngangen til første verdenskrig8.

\section{Den autoritære utviklingsstat}

På begynnelsen av I9oo-tallet begynte en “nasjonal reaksjon” å spre seg i både Iran og Det osmanske riket. Bevisstheten økte om sammenhenger mellom den økonomiske og den politiske krisen, og gryende nasjonalister kritiserte avhengigheten av jordbruk og europeisk kapital. I det nye Midtøsten og Nord-Afrika som fremsto etter Den første verdenskrig, mente man at staten måtte ta konsekvensen av den private sektors manglende kapital og engasjere seg mer aktivt i økonomien for å tvinge frem en industrialisering. Veien var imidlertid fremdeles stengt av vestlig kolonialisme og en klasse av notables som, med unntak av i Tyrkia, dominerte det politiske liv helt frem til I950- og 6o-tallet. Stater som Syria, Libanon, Irak og Jordan oppsto som britiske og franske mandatområder, arvet handels- og landeiereliten fra Det osmanske riket, og skulle møte enorme utfordringer for nasjonsbygging på grunn av sin heterogene befolkningssammensetning. En voksende middelklasse opponerte

\section{Ingen motordrevne fabrikker fantes i Irak for 1914. Situasjonen var ikke bedre i Iran.}

mot vestlig imperialisme og anklaget det lokale "føydalaristokratiet" for å monopolisere det politiske og økonomiske liv. Ved å klatre via det militære systemet som hovedsakelig rekrutterte utenfor rekken av notables og ikke minst i rurale strøk, greide revolusjonære ledere fra lavere middelklasse å ta makten ved statskupp og innføre republikker i land som Egypt (I952), Irak (I958), og Libya (I969). I de tidligere franskdominerte republikkene Syria, Tunisia og Algerie, oppsto liknende regimer med ambisiøse vyer for økonomisk utvikling, omfordeling og nasjonal selvstendighet. Nassers store jordreform fra I954, fulgt av tilsvarende konfiskering i Irak og Syria etter I958, markerte viljen til å knekke den 
gamle jordeierelitens innflytelse. Intellektuelle verden over tolket hendelsene som det endelige brudd med "føydalismen" og regnet med å se fremvekst av et moderne politisk system. Men den nye republikanske orden som blandet sosialisme og arabisk nasjonalisme skulle raskt vise seg å skape sin egen politiske og økonomiske adel, og maktfordelingen uteble.

Det vesentlige for oss i jakten på sammenhenger mellom økonomi og demokrati er at den nye utviklingsmodellen var grunnleggende autoritæ. Det var ikke småborgerskapet som skulle skape vekst og frihet giennom sin dynamiske rolle i det sivile samfunn, men staten som skulle føre folket mot fremskritt gjennom investeringer, reguleringer og sosial utjevning. Politisk var situasjonen preget av ettpartistyre og populisme. Bath-partiene i Syria og Irak eliminerte sine politiske fiender nådeløst, mens FLN som hadde vært en algeirsk opposisjonsallianse under krigen mot Frankrike raskt påberopte seg enerett på å mobilisere massene etter uavhengigheten. Populismen var preget av forestillinger om at nasjonal enhet kunne utviske all konflikt, at den politiske ledelsen var ett med folket og at institusjonell representasjon derfor ikke var nødvendig: "Dere er alle Gamal Abdel Nasser!” skrek den egyptiske presidenten til folkemengden i I954. I motsetning til den liberale nasjonalismen som hadde vært borgerskapets ideologi i kampen mot føydalsystemet i Europa, fremsto den arabiske middelklassens nasjonalisme $i$ en antidemokratisk drakt. Rettere sagt, man kjempet for frihet utad etter gode roo år med vestlig imperialisme i regionen, men glemte å sikre friheten innad, i skyggen av den statsdrevne utviklingen. Spørsmålet er selvfølgelig om man egentlig hadde noe valg. I sin for amerikanske rådgivere svært innflytelsesrike bok fra I968, hevdet Samuel Huntington at alternativet til den autoritære utviklingsmodellen i en periode med intensiv modernisering var kaos ${ }^{9}$ Republikkene i Midtøsten og Nord-Afrika skulle bryte hegemoniet til den gamle overklassen og samtidig føre samfunnet gjennom en smertefull industrialisering. Dette ville medføre så store sosiale omveltninger og uro, mente Huntington, at en "sterk hånd" var påkrevd for å holde korthuset sammen. Økonomisk sett fremsto statsdrevet importsubstitusjon som den eneste strategien som kunne redde utviklingsland fra en avhengig posisjon på verdensmarkedet. I96o-tallets teknokrater glemte imidlertid å forklare hvordan samfunnet skulle gjenvinne kontrollen over morgendagens stadig mektigere stat.

En sammenligning med utviklingen i Tyrkia og Iran illustrerer det samme poenget: statlig beskyttelse og investering var påkrevd for å føre landene gjennom en industrialisering. Men på denne måten ble det staten, og ikke borgerskapet eller arbeiderklassen, som kom sterkest ut av endringen i produksjonsmåte. I Tyrkia beholdt de nevnte grupper større grad av autonomi enn det som var tilfelle i Iran og i den arabiske verdenen, hvilket var en viktig årsak til at pluralismen fikk bedre vilkår. Mustafa Kemal (Atatürk) hadde innledet en periode med massiv statsdreven utvikling i I93I, men etter Den andre verdenskrig åpnet vestlig påvirkning og uenighet $\mathrm{i}$ den byråkratiske eliten for et alternativ til regjeringspartiet RPP, Det demokratiske parti, som vant en overbevisende seier ved valget i 1950. Partiet appellerte til bøndene og småborgerskapet ved å kreve mindre 
statlig inngripen i det økonomiske og religiøse liv. Selv om partiets "liberale fase" ikke skulle bli særlig langlivet, ettersom militære offiserer brøt inn og fjernet det fra makten i I960, hadde Tyrkias politiske elite takket være denne erfaringen gjort seg fortrolig med interessekonflikt og opparbeidet en viss toleranse for deling av makt. I kjølvannet av en ny intensiv industrialiseringsperiode på I96o-tallet begynte innbyggernes økonomiske preferanser å bli så motstridende at de vanskelig kunne skjules under én enkelt ideologi eller karismatisk leder. Tyrkisk nasjonalisme à la Atatürk var fortsatt republikkens absolutte grunnprinsipp, men i mangel av påskudd om kamp mot "kolonimakter" eller "den lokal føydalelite”, kunne ikke militæret sikre stabiliteten uten å ta hensyn til kravene fra en voksende industriarbeiderklasse. Takket være svakere ideologisk innflytelse fra sosialismen hadde kapitalismen dessuten styrket den private industrielle sektor, hvor Turkish Industrialists' and Businessmen's Association (TUSIAD) sto frem som en mektig pressgruppe mot slutten av I970-tallet ${ }^{\mathrm{to}}$. I motsetning til oljestaten Iran kunne ikke den tyrkiske republikken tillate seg å ekskludere alle sosiale grupper fra det politiske rommet.

Sammenlignet med kjerneområdene i Det osmanske riket hadde Iran arvet svakere byråkratiske tradisjoner fra Qajarene (I796-I925) og sterkere innflytelse fra landeiere, stammeledere og den religiøse elite. Fordelen med dette var at samfunnet kunne stille større krav til herskeren, som under den konstitusjonelle revolusjon (I905-I909) hvor notables, intellektuelle og handelsborgerskapet søkte større frihet under det som kanskje kan kalles Midtøsten og Nord-
Afrikas første demokratiske eksperiment. Ulempene var imidlertid senere modernisering, dårligere økonomisk vekst og større indre ustabilitet. De gryende nasjonalistene så derfor opprinnelig med håp på sin nye militære leder, Reza Khan, som skulle krones til sjah i I925 og lansere landets første industrialiseringsprogram i I930. Sjahen og hans sønn ble pådrivere for den samme type autoritære modernisering som de fleste andre land i regionen skulle oppleve, men der Atatürk greide å rotfeste sine reformer gjennom en ideologi, et parti og samspill med privat sektor valgte hans kolleger i Iran å gå alene. Etter at en langvarig allianse med den innflytelsesrike landeierklassen ble ofret for en omfattende jordreform i ig63, i håp om å forvandle landet til en sterk, kapitalistisk industrinasjon, utviklet regimet seg i retning av et personlig diktatur. Tanken var opprinnelig å støtte seg på det private industrielle borgerskapet som i Tyrkia, men ettersom oljeinntektene syntes å stige grenseløst utover I960- og I970-tallet forsvant fort viljen til å samarbeide. Verken det industrielle borgerskapet eller arbeiderklassen var sterke nok til å tvinge gjennom krav om representativt styre: sjahens satsning på olje og tunge, kapitalintensive industriprosjekter hadde resultert $\mathrm{i}$ en forholdsvis liten fabrikkarbeiderklasse og en avhengig privat sektor. Utfordringene for demokratisering i Iran tok mer og mer form av de klassiske problemene, som vi skal se, forbundet med oljeøkonomi og klientelisme.

\section{Olje, stat og demokrati}

Påstanden i det foregående har vært at behovet for statsdrevet økonomisk utvikling i Midtøsten og Nord-Afrika skulle 
bane vei for autoritære ledere og styrke statsapparatet mer enn gruppene som hadde bidratt til å demokratisere Europa etter den industrielle revolusjonen, nemlig arbeiderklassen og borgerskapet. Styrkeforholdet mellom stat og samfunn ble imidlertid ekstra skjevt i regimer som hadde tilgang til store oljeressurser, som Iran, Irak, Libya, Algerie og monarkiene på den arabiske halvøya. Ved å basere økonomien på oljeproduksjon, som krever maskiner, teknologi og kapital, men relativt få arbeidere, oppnådde statene spesielt stor grad av uavhengighet fra de lokale produksjonskreftene. Mellom I963 og I973 utgjorde direkte skatter for eksempel bare $7 \%$ av den iranske regjeringens inntekter ${ }^{\text {II }}$. Likevel økte byråkratiet fra I2 ministerier med I5O ○०० funksjonærer til I9 ministerier med 304000 funksjonærer mellom 1963 og $1977^{12}$. I land som Libya, Saudi-Arabia og Kuwait, hvor folketallet var lavere og næringsstrukturen mindre variert, ble fristillingen enda mer markert: staten trengte etter hvert ingen økonomiske bidrag fra borgerne for å få hjulene til å gå rundt't . Oljemonarkiene i golfregionen begynte tvert imot å subsidiere befolkningen ved å bygge ut omfattende velferdssystemer som garanterte gratis eller svært billig vann, elektrisitet, undervisning, medisinsk behandling osv. Store mengder importert arbeidskraft, hovedsakelig fra sør- og sørøstAsia, men også fra Vesten og resten av den arabiske verdenen, ble ansatt for å tilby slike lukrative tjenester. I De forente arabiske emirater består $80-85 \%$ av innbyggerne av fremmedarbeidere uten statsborgerskap, og andelen er rundt 95\% hvis man bare ser på Dubai. Takket være velferdsstaten, som er blant de aller beste på Den arabiske halvøya, må samtlige av landets borg- ere betraktes som øvre middelklasse/overklasse. Til gjengjeld er den politiske makten utelukkende forbeholdt kongefamilien. Mange har undret seg over at det ikke finnes mer opposisjon i Emiratene eller krav om deltakelse i politiske beslutninger. Men hvis du er så heldig å tilhøre mindretallet med fri tilgang til velferdsgodene, har du mye å tape på å giøre opprør ...

Ved å overlate ansvaret for produksjonen til staten mister folket et av sine viktigste pressmidler i kampen for frihet og demokrati. Litteraturen om rentierstaten beskriver fenomenet som no taxation, no representation ${ }^{14}$ : dersom du ikke betaler skatt kan du heller ikke regne med å kunne påvirke det politiske livet. Problemet er på

\section{Ved å overlate ansvaret for produksjonen til staten, mister folket et av sine viktigste pressmidler.}

sett og vis at Marx blir satt på hodet: staten fremstår ikke lenger som en "overbygning" til produksjonsstrukturen, men snarere som en "basis" for landets økonomiske aktivitet. Takket være rikdommen i naturressursene er det staten, og de som kontrollerer statsapparatet, som styrer fordelingen av kapital. For å ta del i godene må man pleie sine politiske kontakter. Organiseringen har klare likhetstrekk med Max Webers modell, hvor det er forholdet til velgjøreren, og ikke til produksjonsmidlene, som bestemmer innbyggernes plass på den sosiale rangstigen. Fyrsten binder sine undersåtter til seg gjennom et omfattende system av privilegier og goder som han storsinnet distribuerer for å sikre seg 
politisk støtte (såkalt klientelisme). Funksjonsmåten gjenspeiler også stammesamfunnets politiske organisering, hvor ledende sjeiker ble forventet å tilby gaver til andre mektige stammeledere for å sikre deres lojalitet. Klientelismen fungerer imidlertid langt utover det som historisk sett var stammeområder, og fremstår i dag som den mest grunnleggende mekanismen for opprettholdelse av autoritære regimer i Midtøsten og Nord-Afrika. Tilbud om "fordeler" virker nemlig slik at den enkelte borger har økonomiske insentiver for å unnlate å kritisere regimet.

\section{Brutte forventninger}

Siden styrkeforskjellen mellom stat og samfunn har vist seg å være et grunnleggende problem for demokratisering i Midtøsten og Nord-Afrika, håpet mange at løsningen skulle ligge i den privatisering og økonomiske liberalisering som hadde havnet på dagsordenen til samtlige land i løpet av I990-tallet. Statsdrevet økonomisk utvikling basert på importsubstitusjon har nemlig spilt fallitt. For å spytte inn nye midler krever Verdensbanken og Pengefondet at staten slanker underskuddene på statsbudsjettet, kutter ned på reguleringene, og slutter å involvere seg i oppgaver som med fordel kan løses av den private sektor. Utviklingen så langt har imidlertid ikke kunnet innfri forventningene. Etter mer enn 30 år med liberalisering $i$ et land som Egypt er betydningen av de politiske forbindelser fortsatt like stor: For å kunne kjøpe en lukrativ statsbedrift som legges ut for salg, eller for å slippe unna byråkratiske hindre i praksis, må du helst være familie eller "venn" av han som representerer staten. Så lenge det ikke eksisterer demokratisk kontroll, kan ingen hindre makteliten i å bruke privatisering til å styrke sitt private klientell. Dermed forblir vanskeligheten, som vi har sett i denne artikkelen, å fremme en økonomisk elite som ikke samtidig kontrollerer politikken, rettsvesenet og administrasjonen. Det nye borgerskapet blir ingen motmakt til de styrende, men en alliert, som avleder oppmerksomhet fra politikernes utmagring av ressursene ${ }^{15}$. Mye vil selvfølgelig forandre seg når fallende oljeinntekter tvinger landene til å utvikle sin næringsstruktur og hindrer sentralmakten i å kjøpe folks konsensus. Men så langt må vi konkludere med at den økonomiske utviklingen i Midtøsten og Nord-Afrika har virket mot demokratisering: overgangen til en kapitalistisk produksjonsmåte, til oljeøkonomi og til en statlig-autoritæ utviklingsstrategi har på mange måter bidratt til å låse områdets politiske struktur.

\section{$\cdot f \cdot$}

'Privat eiendom fordi all merverdi akkumuleres av staten og stammene, borgerskap fordi det ikke eksisterer privat eiendom, og urbanisering fordi merverdi kun skapes gjennom jordbruk: byene har ingen selvstendig økonomisk basis, men avhenger av statsbyråkratiets evne til å tyne samfunnet for ressurser.

${ }^{2}$ Seymour Martin Lipset: “Some Social Requisites of Democracy: Economic Development and Political Legitimacy". American Political Science Review LIII, mars I959.

${ }^{3}$ Karl A. Wittfogel (I957): «Oriental Despotism: A Comparative Study of Total Power». New Haven, Yale University Press. 
${ }^{4}$ Iran hadde inngått lignende frihandelsavtaler med Russland i I8I3 og I828, og med Storbritannia i I84I.

${ }^{5}$ Dietrich Rueshemeyer, Evelyne Huber Stephens, John D. Stephens (I992): «Capitalist Development and Democracy». Cambridge, Polity Press.

${ }^{6}$ Barrington Moore Jr. (I966): «Social Origins of Dictatorship and Democracy. Lord and Peasant in the Making of the New World». Boston, Beacon Press.

${ }^{7}$ Roger Owen (I993): «The Middle East in the World Economy, I80o-I9I4». London, New York, I.B.Tauris.

${ }^{8}$ Charles Issawi (I97I): «The Economic History of Iran, I80o-I9I4». Chicago, London, The University of Chicago Press.

${ }^{9}$ Samuel P. Huntington: «Political Order in Changing Societies». New Haven/London, Yale University Press, I968.

${ }^{10}$ Hootan Shambayati, “The Rentier State, Interest Groups, and the Paradox of Autonomy. State and Business in Turkey and Iran”, Comparative Politics, April I994.

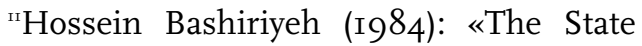
and Revolution in Iran, I962-I982». Kent/Fyshwick, Croom Helm Ltd.

${ }^{\mathrm{I} 2}$ Ervand Abrahamian (1982): «Iran Between two Revolutions». Princeton Jersey, Princeton University Press.

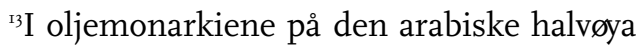
finansieres jevnt over $90 \%$ av budsjettene med eksport av olje.
${ }^{\mathrm{I} 4}$ Se for eksempel Giacomo Luciano (I990): «The Arab State». London, Routledge. "Rentierstat" definert som stater som henter mesteparten av inntektene (minimum 40\%) fra olje eller annen "rente” og står for store deler (minimum 30\%) av BNP.

${ }^{15}$ Libération av 30 oktober 2002 viser for eksempel hvordan ståheien rundt "Algeries første private imperium", Khalifa-gruppen som blant annet driver egen bank og eget flyselskap (men i virkeligheten taper rundt 500 millioner euro i året), er ment å avkrefte forestillingen om at penger bare kan tjenes av den militære eliten. 